\title{
Synthesis and Mechanical Properties of Calcium Sulfoaluminate Cements by using Different Raw Materials
}

\author{
Madan Mohan Reddy. K \\ Department of Civil Engineering \\ SKIT, Srikalahasti, AP, India
}

Srimurali. M

Department of Civil Engineering

S.V. Univeristy, Tirupati, AP, India

Bhaskar. M

Department of Zoology

S.V. Univeristy, Tirupati, AP, India

\begin{abstract}
In the present work, two types of Calcium Sulfoaluminate (CSA) cement clinkers namely CSA-Ref and CSAHYP were synthesized by using one from pure Reagent-grade (RG) chemicals and another from the combination of processed Natural-grade (NG) minerals along with partial replacement of industrial waste Hypo Sludge (HYP) respectively. Raw materials are blended with ultra pure water and blended raw ingredients were collected in alumina crucibles after drying in an oven and then fired in an electric high temperature muffle furnace at $1210^{\circ} \mathrm{C}$ and $1225^{\circ} \mathrm{C}$ withholding for 2 hours for CSA-Ref and CSA-HYP samples respectively. After completion of firing, the synthetic clinkers were ground into fine powder form through ball mill, tested and further mechanical properties were compared.
\end{abstract}

Keywords - Synthesis, CSA Cements, CSA-Ref, CSA-HYP

Notations - $\mathrm{C}_{4} \mathrm{~A}_{3} \$$ :Tetracalcium Trialuminate Sulphate (Ye'elimite), $\mathrm{C}_{2} \mathrm{~S}$ :Dicalcium Silicate, $\mathrm{C}_{12} \mathrm{~A}_{7}$ :Mayenite, CA:Calcium Monoaluminate, , $\mathrm{C}_{5} \mathrm{~S}_{2} \$$ :Ternesite, $\mathrm{C} \$$ :Calcium Sulphate, $\mathrm{C}_{4} \mathrm{AF}$ :Tetracalcium Aluminoferrite.

\section{INTRODUCTION}

The Ettringite or CSA Cements are a type of high alumina cement that first came to prominence in 1970's [1]. Sulfoaluminate cement was developed by introducing $\mathrm{C}_{4} \mathrm{~A}_{3} \$$ and it is known as Klein's compound. The Calcium Sulfoaluminate (CSA) cements are currently receiving a lot of interest because their manufacture produces less $\mathrm{CO}_{2}$ than Ordinary Portland Cement (OPC) and also beneficial use of industrial wastes as raw materials. The CSA Belite cements can exhibit rapid setting, high early-age strength, self-stressing ability, and shrinkage-compensating properties, due to the fast reaction of $\mathrm{C}_{4} \mathrm{~A}_{3} \$$ with calcium sulfates, water and the expansive nature of the primary reaction product, Ettringite $\left(\mathrm{C}_{6} \mathrm{~A} \$_{3} \mathrm{H}_{32}\right)$ [2].

The laboratory production of three aluminum-rich BSA clinkers with nominal mineralogical compositions in the range $\mathrm{C}_{2} \mathrm{~S}$ (50-60\%), $\mathrm{C}_{4} \mathrm{~A}_{3} \$(20-30 \%), \mathrm{CA}(10 \%)$ and $\mathrm{C}_{12} \mathrm{~A}_{7}$ (10\%) were studied [3]. Special cements based on CSA, can be successfully synthesized at a laboratory scale from raw mixes containing Limestone, Bauxite, Fluidized bed combustion bottom and/or Fly ash heated at $1200^{\circ} \mathrm{C}-1300^{\circ} \mathrm{C}$ [4]. 
When compared to Tricalcium silicate $\left(\mathrm{Ca}_{3} \mathrm{SiO}_{5}\right)$, which releases $0.578 \mathrm{~g}$ of $\mathrm{CO}_{2}$ per gram of the cementing phase

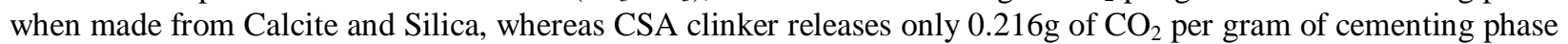
when made from Limestone, Alumina and Anhydrite. All of the phases in CSAB cement can form and are stable at a temperature of approximately $1250^{\circ} \mathrm{C}$, which is about $200^{\circ} \mathrm{C}$ lower than the temperature used for Portland cement production. The lower formation temperature further lowers the energy requirement and reduces $\mathrm{CO}_{2}$ emissions from cement manufacturing, and the resulting clinker is more friable (due to a high porosity), which also reduces the energy needed for grinding [5].

In this paper, two types of CSA cement clinkers namely CSA-Ref and CSA-HYP were synthesized by using pure RG chemicals and another from the combination of processed NG minerals along with partial replacement of (HYP) respectively. After completion of firing, the synthetic clinkers were ground into fine powder form through ball mill, tested and further mechanical properties were compared.

\section{MATERIALS AND METHODS}

\section{A. Raw Materials -}

The oxide composition of raw materials were collected and used for preparation of CSA-Ref and CSA-HYP samples and are presented in Table 1. The RG chemicals were obtained from standard make, NG are collected from Astra Chemicals, Chennai, India and HYP was obtained from M/s Delta Paper Mills Ltd, Bhimavaram, Andhra Pardesh, India.

The clinkers sample were synthesized based on potential target phase clinker compounds estimated by modified Bogue compounds method [6] and is shown in Table 2, which produces better mechanical performances. A phase composition with equal (40\%) $\mathrm{C}_{2} \mathrm{~S}$ and $\mathrm{C}_{4} \mathrm{~A}_{3} \$$ contents to have a good balance between CSA Belite cement property development and dimensional stability [7] and were, therefore, chosen as the nearest target phase composition for this study.

The CSA-Ref sample is made from pure RG chemicals and the other sample CSA-HYP prepared with the 85\% NG minerals along with partial replacement of 15\% HYP. Raw mixtures of samples were presented in Table 3.

Table -1 The Oxide Composition of raw materials used.

\begin{tabular}{|c|c|c|c|}
\hline $\begin{array}{c}\text { Oxide } \\
\text { Composition }\end{array}$ & RG & NG & HYP \\
\hline $\mathrm{CaO}$ & $\begin{array}{l}96 \% \text {; } \\
\text { Merck }\end{array}$ & $\begin{array}{l}\text { 98.2\%, Oyster } \\
\text { Shell CaCO }_{3}\end{array}$ & 46.20 \\
\hline $\mathrm{SiO}_{2}$ & $\begin{array}{l}\text { 95\%; } \\
\text { Merck }\end{array}$ & 99.6\%, Quartz & 9.00 \\
\hline $\mathrm{Al}_{2} \mathrm{O}_{3}$ & $\begin{array}{l}\text { 98\%; } \\
\text { Merck }\end{array}$ & $\begin{array}{c}87.2 \% \text {, Aluminum } \\
\text { Powder }\end{array}$ & 3.60 \\
\hline $\mathrm{Fe}_{2} \mathrm{O}_{3}$ & $\begin{array}{c}93 \% ; \\
\text { Qualigens }\end{array}$ & $90 \%$, Ferric Oxide & --- \\
\hline $\mathrm{CaSO}_{4}$ & $\begin{array}{l}\text { 99\%; } \\
\text { Merck }\end{array}$ & 88\%, Gypsum & 4.05 \\
\hline MgO & --- & --- & 3.33 \\
\hline $\begin{array}{c}\text { Trace } \\
\text { Elements }\end{array}$ & --- & --- & -- \\
\hline L.O.I & --- & --- & 38.26 \\
\hline
\end{tabular}

Table -2 Potential Target Phase Clinker Compounds.

\begin{tabular}{|c|c|c|c|c|c|}
\hline $\begin{array}{c}\text { Clinker } \\
\text { Compound }\end{array}$ & $\mathrm{C}_{4} \mathrm{~A}_{3} \$$ & $\mathrm{C}_{2} \mathrm{~S}$ & $\mathrm{C} \$$ & $\mathrm{C}_{4} \mathrm{AF}$ & $\mathrm{C}$ \\
\hline $\mathrm{Wt} \%$ & 42.70 & 37.27 & 12.6 & 7.60 & 0 \\
\hline
\end{tabular}

Table -3 Raw mixtures of samples, wt $\%$

\begin{tabular}{|l|l|l|c|}
\hline \multicolumn{2}{|c|}{ 1. } & CSA-Ref & \multicolumn{2}{c|}{ 2. CSA-HYP } \\
\hline $\mathrm{CaO}$ & 40.50 & HYP & 15 \\
\hline $\mathrm{SiO}_{2}$ & 13.00 & Oyester Shell Powder & 19.65 \\
\hline $\mathrm{Al}_{2} \mathrm{O}_{3}$ & 23.00 & Quartz & 11.70 \\
\hline $\mathrm{Fe}_{2} \mathrm{O}_{3}$ & 2.50 & $\begin{array}{l}\text { Aluminium } \\
\text { Powder }\end{array}$ & 25.78 \\
\hline $\mathrm{CaSO}_{4}$ & 21.00 & Iron & 2.78 \\
\hline-- & -- & Gypsum & 25.10 \\
\hline
\end{tabular}

\section{B. Synthesis of Cement Clinker-}

The proportioned raw mixtures shown in Table 3 were blended with ultra pure water (1:2 ratios) by using an aluminium-mixer jar for 1 hour at 100 RPM. The blended solutions were transferred to ceramic crucibles and dried in 
a laboratory oven at $103^{\circ} \mathrm{C}$ for 24 hours based on previous study [8]. The resulted materials were crushed into fine powder by using a mortar and pestle. This powder samples were collected in alumina crucibles and then submitted for firing in an electric high temperature muffle furnace at $1210^{\circ} \mathrm{C}$ and $1225^{\circ} \mathrm{C}$ withholding for 2 hours for CSA-Ref and CSA-HYP samples respectively. After completion of firing, the synthetic clinkers were ground into fine powder form through ball mill, tested and further mechanical properties were compared.

\section{RESULTS AND DISCUSSIONS}

Tests conducted on CSA cements for mechanical properties such as Specific Gravity, standard consistency, Initial \& Final setting times, Soundness and Workability tests were conducted according to IS:4031-1988 [9] and performance of Compressive strength tests were performed on the $5 \mathrm{~cm} \times 5 \mathrm{~cm} \times 5 \mathrm{~cm}$ cement mortar cubes in accordance with ASTM C109 [10]. The results of mechanical properties CSA cement samples were shown in Table 4. The specific gravity of both CSA-Ref and CSA-HYP cement samples were observed same and noted as 3.157 and it is also compatible with specific gravity of OPC. The standard consistencies were observed as $22 \%$ and $24 \%$ for CSA-Ref and CSA-HYP cement samples respectively. The observed standard consistency shows that it requires the amount of water required to produce plastic mix are lower than the OPC (30-32\%).

The Initial and Final setting times were observed at $9 \mathrm{~min}$ and $11 \mathrm{~min}$ for CSA-Ref and cement sample respectively. The observed initial setting times indicate that both samples set rapidly (flash-set). The final setting times were observed at $24 \mathrm{~min}$ and $27 \mathrm{~min}$ for CSA-Ref and CSA-HYP cement samples respectively and this indicates that hardening of cement paste was completed in short time. Both samples results gave lower values of initial and final setting times as compared to setting times of OPC, thus indicating these are of Rapid Set Cements [11]. Soundness of cement is determined by Le-Chatelier method, the observed values of soundness was $1.5 \mathrm{~mm}$ for both CSA-Ref and CSA-HYP cement samples. This indicates that both CSA cement samples were the same expansive character. The workability (w/c ratios) was kept 0.41 and 0.48 for CSA-Ref and CSA-HYP cement samples respectively.

The 1, 3, 7, 21 and 28 days moist curing ages of the cement mortar cube compressive strength was measured and the results of CSA cement samples were shown in Table 5 and Figure 1 Compressive strength of CSA-Ref sample at all ages of curing days increases steadily and significantly and for CSA-HYP sample was shown lower compressive strength at all ages as compared to CSA-Ref sample, since CSA-HYP prepared with $85 \%$ NG and 15\% HYP, which contains impurities.

Table -4 Mechanical properties of CSA cement samples.

\begin{tabular}{|l|c|c|}
\hline Properties & CSA-Ref & CSA-HYP \\
\hline Specific gravity & 3.157 & 3.157 \\
\hline Standard Consistency, \% & 22 & 24 \\
\hline Initial Setting Time, min & 9 & 11 \\
\hline Final Setting Time, min & 24 & 27 \\
\hline Soundness, mm & 1.50 & 1.50 \\
\hline $\begin{array}{l}\text { Workability of Mortar, } \\
\text { w/c Ratio }\end{array}$ & 0.41 & 0.48 \\
\hline
\end{tabular}

\section{CONCLUSIONS}

In this paper, utilization of different raw materials in the production of CSA cements was studied. CSA clinkers were produced successfully at lower temperatures of $1210^{\circ} \mathrm{C}$ and $1225^{\circ} \mathrm{C}$ for CSA-Ref and CSA-HYP samples respectively and which is less than OPC needed. CSA cements reduce energy consumption and lower $\mathrm{CO}_{2}$ emissions 


\section{International Journal of Innovations in Engineering and Technology (IJIET) \\ http://dx.doi.org/10.21172/ijiet.83.010}

because of low lime requirement. Present study, the CSA-HYP sample synthesized from optimum utilization materials of $15 \%$, HYP indicating that the adapted target phase clinker compounds can effectively predict the mechanical properties of samples. Compressive strength of CSA-Ref sample at all ages of curing days the strength increases steadily and significantly and for CSA-HYP sample were showed lower compressive strength at all ages as compared to CSA-Ref sample, since it was prepared to NG minerals and industrial waste HYP which present impurities.

Finally, the use of industrial waste HYP and NG minerals reduces the use of expensive RG raw materials in CSA cements, thereby reducing the cost and the environmental pollution impact of cement manufacturing.

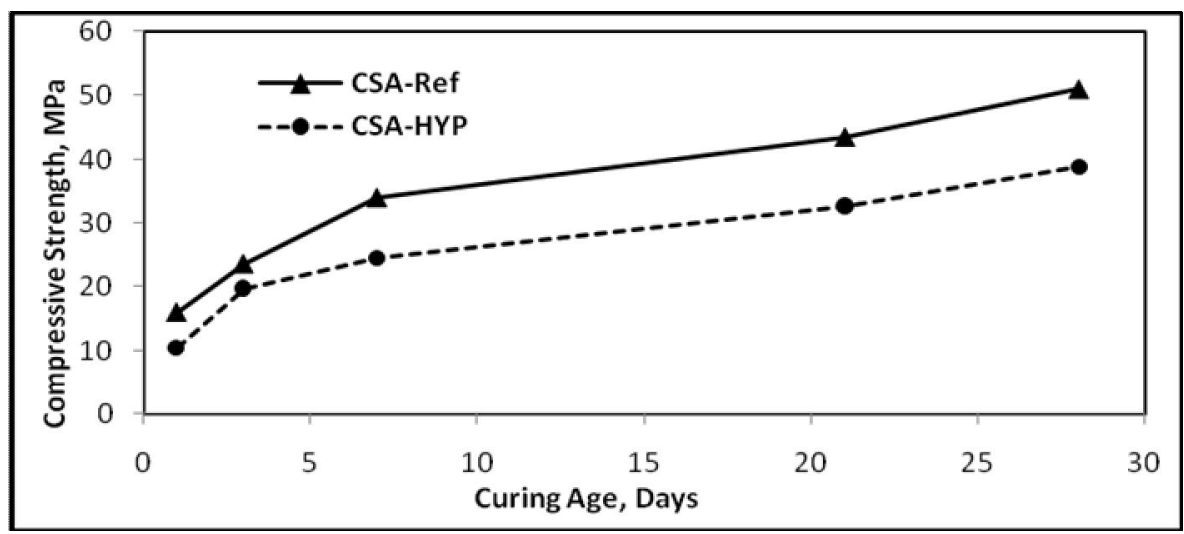

Figure -1 Compressive Strength results of CSA Cement Samples.

\section{REFERENCE}

[1] L. Zhang and M. Z. Su. Y. Wang, "Development of the use of sulfo and ferroaluminate cements in China, Advances in Concrete Research," vol. 11, pp. 15-21, 1999.

[2] A. Irvin. Chen and C. G. Maria. Juenger, "Incorporation of coal combustion residuals into calcium sulfoaluminate-belite cement clinker," Cement \& Concrete Composites, vol. 34, pp. 893-902, 2012.

[3] S. M. Carmen Martin, J. M. Antonio, G. De. La. Angeles Torra, A. P. Gema, M. Luis, A. G. Miguel, “Aluminum-rich belitesulfoaluminate cements: Clinkering and early age hydration," Cem and Conc Research, vol. 40, pp. 359-369, 2010.

[4] G. Belz., P. Caramuscio, M. F. Marroccoli Montagnaro, M. Nobili, A. Telesca and G. L. Valenti, "Fluidized bed combustion waste as a raw mix component for the manufacture of calcium sulphoaluminate cements," Proceedings of the 29th Meeting of the Italian Section of The Combustion Institute, Pisa, Italy, 2006.

[5] F. P. Glasser. and L. Zhang, "High-performance cement matrices based on calcium Sulfoaluminate -belite composites," Cem and Conc Research, vol. 31, pp. 1881-86, 2001.

[6] I. A. Chen, "Synthesis of Portland Cement and Calcium Sulfoaluminate-Belite Cement for Sustainable Development and Performance," PhD Dissertation, The University of Texas at Austin, 2009.

[7] I. A. Chen and M. C. G. Juenger, "Synthesis and hydration of calcium Sulfoaluminate-belite cements with varied phase compositions," J Material Science, vol. 46, pp. 2568-77, 2011.

[8] K. Madan Mohan Reddy, M. Srimurali and M. Bhaskar, "Studies on Synthesis and Mechanical Properties of Calcium Sulfoaluminate Cements by using Marble Waste Powder as a Raw Material," International Journal of Advanced Information Science and Technology, vol. 25(25), pp. 29-31, 2014.

[9] Specifications for Methods of physical tests for hydraulic cement, IS 4031:1988: Bureau of Indian standards, New Delhi.

[10] Specifications for Standard Test Method for Compressive Strength of Cylindrical Concrete Specimens. ASTMC39/C39M:2009, American Society for Testing and Materials, west Conshoho-cken, Pennsylvania.

[11] Specifications for Rapid Hardening Portland Cement, IS 8041:1990: Bureau of Indian standards, New Delhi. 